\title{
A Glimpse at Ethiopian Universities from Globalisaton Perspectives: Institutional Policy Responsiveness for Local and Global Realities
}

\author{
Teklu Tafase Olkaba \\ Assistant professor, Jimma University \\ College of Education \& Behavioral Sciences, Ethiopia \\ Kitessa Chemeda Edosa \\ Assistant professor, Mettu University, \\ Institute of Education \& Professional Development Studies, Ethiopia
}

\begin{abstract}
The impact of globalisation on higher education institution policies and government development policies are emerging issues among researchers and policy makers. The study explored a range of literature on globalization policy and its impact on higher education operations. Based on the literature review, the empirical study examined realities of understanding in Ethiopian higher education and its institutional policy responsiveness to the current local and global knowledge economy. The study was framed with the research question: To what extent have universities in Ethiopia embraced the reality of globalisation? Six experienced Ethiopian universities were purposively selected for the study. From these universities 289 postgraduate students and 256 senior staff from the ranks of lecturer, assistant professor and associate professor were involved in the study. The findings of the study conclude that in the global knowledge economy, the role of Ethiopian universities requires a change in policies and practices and systems, with respect to local and global contexts towards the creation of a distinctly new global model of higher education.
\end{abstract}

Key terms: Globalisation, Internationalisation, Higher Educational Institutions, Global Higher Education Policy, Knowledge Economy, Ethiopia

\section{INTRODUCTION}

The emergence of the global knowledge economy has put a premium on learning throughout the world, which relies primarily on the use of ideas rather than physical abilities and on the application of technology rather than the transformation of raw materials or the exploitation of cheap labor. The global knowledge economy is transforming the demands of the labor market throughout the world. It is also placing new demands on citizens, who need more skills and knowledge to be able to function in their day-to-day lives. In the current transformation of nations into knowledge economies and knowledge societies, higher education provides not only educated workers but also knowledge workers who contribute to the growth of the economy. Higher education is ranked among the chief concern of nation states as it plays a tremendous role in shaping and preparing nations for the future in an increasingly globalized world(Ashcroft, 2011).Since the endorsement of the current education and training policy of 1994, Ethiopia has engaged in a highly ambitious effort to re-align its higher education system more directly to its national strategy for economic growth and poverty reduction. The reforms have targeted all levels: the overall system, the institutions, and the academic programme(Teshome, 2003). The number of universities changed drastically from two universities to 31 universities within the last twenty years. Within this expansion an attempt 
was made to diversify disciplines andhuman resource requirements in all development sectors (MOE, 2010).

The massification of university enrollments in science, engineering and technology is the result of the new strategic approach of the government of Ethiopia. In this context, the government of Ethiopia is focusing on helping its tertiary education institutions to become more innovative and responsive to the requirements of a globally competitive knowledge economy. However, the question of policy viability with the notion of globalisation and the actual practices of the higher education institutions need critical investigation so as to harmonise them with globalisation policy notions.

\section{THE IMPACT OF GLOBALISATION ON HIGHER EDUCATION POLICY}

As globalisation is leading the world under one umbrella, institutions of higher education should have a responsive policy to this global discourse in which the economic and political structures become more and more intersected by reliable and viable policies.Marginson and van der Wende (2009:18) clearly depict the impact of globalisation as follows:

Now the growing impact of the global environment is inescapable. In many nations international mobility, global comparison, bench-marking and ranking, and the internationalisation of institutions and systems are key policy themes, and governments and university leaders are preoccupied by strategies of cross-border co-operation and competition.

The impact of globalisation on higher education offers exciting new opportunities for study and research unlimited by national boundaries, joint degree programmes, 'twinning' efforts, and other approaches to cross-border education (Tefera, 2008: 30) which is seen as an opportunity to have a positive influence on the volume, quality and spread of knowledge through increased interaction among the various states. According to Verger (2010:49) the global impact on education policy is clearly described in different mechanisms as follows:

- Imposition: external actors compel some countries to take on particular education policies (the classic example being the conditionality to credit of the World Bank, the IMF and other aid agencies to borrower countries).

- Harmonization: a set of countries mutually agree on the implementation of common policies in a certain policy area (e.g. the configuration of the European Space for Higher Education).

- Dissemination: external agents use persuasion and its technical knowledge to convince countries on the implementation of certain policies (e.g. through annual reports, best practices data-bases and technical assistance).

- Standardization: the international community defines and promotes the adhesion to a set of policy principles and standards that frame the countries' behavior (e.g. international performance tests, such as standardization of curricular content at the global level).

- Installing interdependence occurs when countries agree to achieve common objectives to tackle problems that require international cooperation.

In order to produce global citizenship, higher education is expected to revisit and integrate international components into their curriculum to meet students' expectations for developing global competencies so that they can be successful in a world society sustaining economic competitiveness in an increasingly global marketplace with common trans-border interests(Altbach, Reisberg\&Rumbley, 2009). These diverse demands on higher education 
internationally are challenging the ability of higher education institutions to prepare global citizens. Even though the risk assessment varies from region to region based on the relative strength and standing of specific higher education institutions, research suggests that the overall perception of risk associated with internationalisation of higher education is higher in the developing world (Knight, 2006). African higher education is the most challenged institution compared to developed counties due to the 'borderless' higher education market in which higher education in developed countries promote their services in Africa (Oyewole, 2010: 19-30).

In the current globalised environment, international actors and educational and extraeducational factors originating at supra-national scales are affecting national education policies, priorities and outcomes. An important part of the educational changes are embedded within interdependent local, national and global political economy complexes (Verger 2010). It is obvious that higher education operates in a globally competitive market and governments everywhere are concerned to maximize their higher education institutions' contribution to the knowledge economy through the "world-Class" research university (Ordorika,2006:5). The connotation means that world-class universities are part and parcel of globalization. Ordorika (2006:5) explains the impact of globalisation on higher education ranking as follows:

Globalisation has added a new element to competition and stratification in higher education. Research universities have always competed with each other for social and academic prestige, and also have long engaged in cross-border activity at their margin. Now for the first time we can identify a single system of world-wide higher education: a network of web-sites joined by instant messaging and data transfer, in which global connections run through the center of institutions and governments and are integral to day-to-day practices. At the same time global people mobility in higher education has substantially increased. In turn global communications and mobility have created conditions for the emergence of a global market in higher education, i.e. competition among elite universities is now worldwide and is moving closer to capitalist economic forms.

As clearly demonstrated by Knight (2007) and Ordorika (2006), the neoliberal policy ideology practices and global competition equally impact and challenge the operation of contemporary higher education in a multi-dimensional way. Global challenge and competition is forcing higher education to innovate local practice (Marmolejo \& Puunka, 2006). MarmolejoandPuunka (2006:11-12) further stipulate:

If countries want to be globally competitive, regional innovation systems need to be strengthened. In order to achieve this, cooperation between higher education institutions becomes vital. Currently, many regions are characterized by an abundance of activity involving higher education in regional development in some way, but there is limited evidence of coherent action in regional engagement, academic excellence, and research activities.

This demonstrates that globalisation has a tremendous impact on the operations of higher education institutions; it reshapes cultures and the diversity debate and forces the immediate need for curricular and support services change at institutions of higher education. The tremendous impact of globalisation is articulated by Aarts and Greijn (2010:9) when they say:

The process of globalisation is changing the ways in which knowledge is produced, applied and disseminated. Universities, the most important institutions in the 
organisation of research and higher education, need to rethink their roles and functions, and develop their capacities to anticipate and respond to these challenges.

As economies around the world move progressively toward the production of knowledge, or a knowledge economy, trade in knowledge and knowledge-based processes becomes more important and lucrative than the manufacture of material products (Coulby, 2005; Varghese, 2008). According to Green (2006), higher education is critical to national economic development in the knowledge economy for its role in both knowledge production and the training of knowledge workers. Although knowledge is now being produced in a variety of organizations around the world, universities remain very important in the hierarchy of knowledge production (Yang, 2002; Coulby, 2005). Coulby (2005) contends that while globalisation has an overall tendency to reduce the traditional national character of higher education institutions and differences between national systems, it still has to contend with the influence of national policy structures which shape higher education policy.

It is clear that the discourse of globalisation is hugely influential and impacts on higher education institution policy (van der Wende, 2005). Therefore, higher education institutions should commit to reform their policies.MarmolejoandPunka (2006), one of the roles of higher education should be its engagement in local development activities for the development of local societies that impact on global market competition. In order to realize equitable global competition, higher education (UNESCO, 2009:97) should develop:

- responsive policy to global discourses

- responsive policy to the world of work

- responsive policy to levels of the education system,

- responsive policy to local development and cultures

- responsive policy to research, quality assurance

- responsive policy to everywhere and all the time.

The global environment in which higher education operates today is wide in its range and faces complex and conflicting interests and interactions. Both local and global demands require careful attention by policy makers to make institutions interactive in the global and local contexts. Therefore, in order to maintain the balance of globalisation discourses higher education needs responsive policies and strategies to maximizeopportunities and benefits of globalisation while ensuring local development as well. Therefore, the relevance of global higher education means being responsive to global discourses, the world of work, levels of the education system,local development and cultures,research, quality assurance and graduating students and teachers.

In conclusion, to narrow the gaps and minimise the challenges, the principle of thinking globally and acting locallyhelps with setting general standards and procedures for higher education institutions.Thus, inthe global knowledge economy, higher education needs changed policies and practices,changed systems with respect to national and regional contexts and a distinctly new global model.

\section{THE CURRENT ETHIOPIAN HIGHER EDUCATION STATUS}

The government of Ethiopia has been engaged in a highly ambitious and aggressive expansion policy of higher education to re-align its higher education system in order to contribute more directly to its national strategy for economic growth and poverty reduction for the last twenty years. As the result of an aggressive expansion policy, the country's public universities increased from two to 32 universities and enrollment increased from 35000 in 1996 to 534978 
in 2014 with a total of academic staff of 22201 engaged in teaching-learning and research in public universities of Ethiopia (MoE, 2014).

In addition to expansion, programme diversification and graduate mix policy introduced in 2009 by the Ministry of Education stipulates that all universities should modify their curricula so that $70 \%$ of student intake is in the science-engineering and technology disciplines and $30 \%$ is in the arts and humanities. The implication of graduate mix policy is that there will be approximately 375000 graduates within every five years with about $20 \%$ increment in science-engineering and technology streams. However, the policy viability is not clearly articulated for science and technology graduates who should meet the needs of local and global market (Ashcroft, 2011).

Aggressive expansion of higher education in Ethiopia is challenged by the need to serve a total population of about 90 million people, according to 2012 projection, of which $83 \%$ are rural. The labor force estimated that of 47 million persons in different development sectors, $80 \%$ of the population are engaged in agriculture, much of which is subsistence agriculture (MOFED,2011). The country's economic growth strategy is based on agriculture-led development that emphasizes technology transfers, improving agricultural production and rural extension, irrigation development and fertilizer supply and enhancing overall labor productivity through better education, research and innovation (MOE,2010). The aggressive expansion of Ethiopian universities are not producing enough graduates to meet the needs of the local market economy, while still the local market economy suffers from a lack of high caliber graduate in fields of technology (Mulu,2012).On the other hand the expansion and program diversification of Ethiopian higher education is aimed at socio-economic transformation. However, the linkage of universities with societal transformation is loosely linked with society. This suggests that Ethiopian universities' policy responsiveness to local engagement is problematic.

Moreover, Ethiopian universities are attempting to reform their education system to meet the standards of the Bologna process. However, in Ethiopia, because of differences in demography, levels of academic infrastructure and the local challenges, effective Ethiopian higher education harmonization takes time. Thus, the alignment of the Ethiopian higher education National Qualifications Framework with that of the other globally recognised institutions is another challenge for the relevance of Ethiopian higher education qualifications in the current global arena. Therefore, to narrow the gaps and minimise the challenges, the principle of thinking globally and acting locallyhelps standards and procedures for Ethiopian universities while incorporating the Bologna process and other global demands into a comparable and reliable policies.Therefore, the study is expected to fill the gap observed and suggest a new policy direction for Ethiopian higher education institutions.

\section{METHODS OF THE STUDY}

The first step made in conducting this study was making critical review on nature of globalization and its discourses, in relation to higher education policies and practices. The study explored theoretical framework, extensive literature review and recent empirical studies on impacts of globalisation on higher education system and its discourse at local, national and global level. Thus, the intensive review made helps the researcher to understand impact of global policies in general of higher education in particular. Document analyses provided a foundation and framework of understanding from which detailed empirical research was used to explore the phenomena at the center of this study, policies and practices of Ethiopian universities. Based on the document analysis and extensive review made survey questionnaires and focus group discussion was conducted with senior and experienced 
sampled Ethiopian universities. Basically, the data collection for this study on Ethiopian higher education policies and practices in response to globalization entailed:

- An analysis of official documents that provided insight into institutional system policies and guidelines and international initiatives.

- A survey questionnaire and focus group discussions which provided insight into realities of understanding impact of globalization on higher education the policies and practices in teaching and learning.

\section{Participants}

In this study, out of a population of 1572 senior academic staffs from the six institutions combined, 345 respondents from the rank of lecturer and above with at least five years' experience in teaching, research and community service were purposefully selected. The criterion for inclusion for academic staff was based on years of experience, academic rank and engagement in teaching learning, research and community services. Out of a population of 2 460 postgraduate students from the six institutions combined, 311 postgraduate students were also purposefully selected. The criteria employed to select postgraduate student was based on their availability in the campus and level of their study years and specialization. Table 1 showsthe respondents per rank: $26.40 \%$ lecturers, $14.50 \%$ assistant professors and $6.10 \%$ associate professors and $53.0 \%$ were postgraduate students.

For focus group discussion nine key informants per institution, selected purposively on the basis of their rich experience in teaching and research experience at institutions of higher learning, participated in focus group discussions which comprised of a total of 54 participants. These participants were selected among assistant and associate professors and $\mathrm{PhD}$ students from each university who participated in survey questionnaire. The sampling technique employed was subjected to the nature of the problem and the chosen paradigm, the mixed approach in this case. The focus group was represented as follows: 8 associate professors; 12 assistant professors; 20 lecturers and $14 \mathrm{PhD}$ students. They were chosen purposefully on the basis of their rich experience in higher education and other working environments.

\section{Data Analysis}

The methods of data analysis depend on the nature of the study and its design. As a result there are different approaches of data analysis for different study designs. In this case both qualitative and quantitative data were integrated into each set of research questions.

The questionnaires were analyzed by a designated statistician who made use of the Statistical Package for Social Sciences (SPSS 20) computer software. This computer programme uses cross tabulations to determine the relationship between numerous variables simultaneously. The quantitative data were reduced into descriptive statistics such as percentages, chi-square tests and inferential statistics such as one-way ANOVA. The qualitative data drawn from focus group discussions, official documents and recent reviews supplements the quantitative data. Finally, a holistic approach to analysis incorporated findings from both quantitative and qualitative data. The themes for the data analyses were derived from the conceptual framework of the study that was grounded in the basic research questions. The findings of the quantitative data was described first and then supplemented by qualitative findings in the form of texts and quotes. Thematic issues and the evidence generated from the focus group discussion and document analysis were integrated with the quantitative data generated from the questionnaire with reference to the original research questions. 


\section{PRESENTATION AND DISCUSSION OF THE FINDINGS}

The composite frequency (Table 1) presents the findings regarding the respondents' conceptual understanding of globalisation in Ethiopia. The response pattern of respondents on individual items regarding the extent to which universities in Ethiopia embrace the reality of globalization is illustrated.

Table 1: Respondents' extent of understanding of realities of globalisation

\begin{tabular}{|c|c|c|c|c|c|c|}
\hline Descriptions & Respondents & $\mathrm{N}$ & $M$ & SD & $F(3,543)$ & $p$ \\
\hline \multirow{5}{*}{$\begin{array}{l}\text { Conceptual } \\
\text { understanding of the } \\
\text { realities of globalization }\end{array}$} & Lecturer & 169 & 3.8 & 0.55 & \multirow{4}{*}{9.77} & \multirow{4}{*}{0.00} \\
\hline & Assistant professor & 64 & 3.64 & 1.01 & & \\
\hline & Associate professor & 22 & 4.44 & 0.62 & & \\
\hline & $\begin{array}{l}\text { Postgraduate } \\
\text { students }\end{array}$ & 289 & 3.93 & 0.6 & & \\
\hline & Total & 544 & 3.87 & 0.67 & \multirow{5}{*}{2.17} & \multirow{5}{*}{0.09} \\
\hline \multirow{5}{*}{$\begin{array}{l}\text { Responsiveness of } \\
\text { teaching and learning } \\
\text { policy on global } \\
\text { knowledge economy }\end{array}$} & Lecturer & 166 & 3.17 & 0.75 & & \\
\hline & Assistant professor & 64 & 3.01 & 0.93 & & \\
\hline & Associate professor & 22 & 2.86 & 0.89 & & \\
\hline & $\begin{array}{l}\text { Postgraduate } \\
\text { students }\end{array}$ & 287 & 3.24 & 0.8 & & \\
\hline & Total & 539 & 3.18 & 0.81 & \multirow{5}{*}{1.65} & \multirow{5}{*}{0.17} \\
\hline \multirow{5}{*}{$\begin{array}{l}\text { Responsiveness of } \\
\text { research and innovation } \\
\text { policy on global } \\
\text { knowledge economy }\end{array}$} & Lecturer & 164 & 3.12 & 0.7 & & \\
\hline & Assistant professor & 64 & 3.14 & 0.92 & & \\
\hline & Associate professor & 22 & 2.8 & 1.07 & & \\
\hline & $\begin{array}{l}\text { Postgraduate } \\
\text { students }\end{array}$ & 283 & 3.2 & 0.9 & & \\
\hline & Total & 533 & 3.15 & 0.85 & \multirow{5}{*}{7.30} & \multirow{5}{*}{0.00} \\
\hline \multirow{5}{*}{$\begin{array}{l}\text { Responsiveness of } \\
\text { university policies on } \\
\text { local and global } \\
\text { engagement }\end{array}$} & Lecturer & 158 & 3.28 & 0.88 & & \\
\hline & Assistant professor & 63 & 3.17 & 1.08 & & \\
\hline & Associate professor & 22 & 2.22 & 1.17 & & \\
\hline & $\begin{array}{l}\text { Postgraduate } \\
\text { students }\end{array}$ & 278 & 3.17 & 1.03 & & \\
\hline & Total & 521 & 3.16 & 1.02 & \multirow{5}{*}{2.20} & \multirow{5}{*}{0.09} \\
\hline \multirow{5}{*}{$\begin{array}{l}\text { Responsiveness of } \\
\text { university policy on } \\
\text { graduate employment } \\
\text { demand in the global } \\
\text { context }\end{array}$} & Lecturer & 150 & 2.53 & 0.92 & & \\
\hline & Assistant professor & 64 & 2.31 & 1.11 & & \\
\hline & Associate professor & 21 & 1.7 & 1.24 & & \\
\hline & $\begin{array}{l}\text { Postgraduate } \\
\text { students }\end{array}$ & 263 & 2.55 & 1.21 & & \\
\hline & Total & 498 & 2.48 & 1.13 & & \\
\hline
\end{tabular}

* M: Mean, SD: Standard Deviation

Table 1 depicts that academic staff and students at the selected institutions had a good understanding of the realities of globalisation. The overall descriptive statistics on the realities of globalisation ( $M=3.87, S D=.67)$ show that academic staff and students were well aware of the realities of globalization according to the literature review on the current global discourses. The responsiveness of the teaching and learning policy on the global knowledge economy in the selected universities did not seem satisfactory. The descriptive statistics $(\mathrm{M}=3.18, \mathrm{SD}=$ 0.81) demonstrate that all respondents rated that little or medium efforts had been made by universities to ensure that policies on teaching and learning responded to the global demands. The associate professors rated the extent to which the teaching and learning policy responded to the current global demand extremely low ( $\mathrm{M}=2.86 \& \mathrm{SD}=0.89)$.

Table 1 further describes the responsiveness of the research and innovation policy on global knowledge demand and on local and global engagement $(M=3.15 \& S D=0.87$ and $M=3.16$ \& $\mathrm{SD}=1.02)$. The descriptive statistics depict that the responsiveness of research and innovation 
policy on global demand is not satisfactory. Furthermore, the associate professors' responses regarding theresponsiveness of the research and innovation policy on global knowledge demand and on local and global engagement $(\mathrm{M}=2.80 \& \mathrm{SD}=1.07 ; \mathrm{M}=2.22 \& \mathrm{SD}=1.17)$ respectively, shows that Ethiopian universities response to current globalisation demands is weaker.

In relation to theresponsivenessof the university policy on graduate employment demands in the global context, the role played by Ethiopian universities with regard to graduate job placement was extremely poor, or no attempt was made at all. According toTable 1 , the overall mean of the respondents $(\mathrm{M}=2.48, \mathrm{SD}=1.13)$ shows that few or no attempts were made to follow up graduates and their placement at local or global level after completion of acertain level of education. In other words, there was no institutional policy to undertake tracer studiesof the required workplace demands on both the local and global contexts in the respective fields or disciplines offered at universities.

Table 1 further shows that a statistically significant differences $\left(F_{(3,543)}=9.77, p=0.00\right)$ among the respondents on the realities of the globalisation and institutional policies on local and global engagement $\left(F_{(3,543)}=7.30, \mathrm{p}=0.00\right)$.To understand these significant differences better, a post hoc analysis was undertaken as can be seen in Table 2 below 
Table 2: Analysis of respondents' difference on realities of globalisation

\begin{tabular}{|c|c|c|c|c|c|}
\hline Dependent Variable & & & $\begin{array}{l}\mathrm{MD} \\
(\mathrm{I}-\mathrm{J})\end{array}$ & S.E & $P$ \\
\hline \multirow{6}{*}{$\begin{array}{l}\text { Conceptual } \\
\text { understanding of the } \\
\text { realities of } \\
\text { globalization }\end{array}$} & \multirow{3}{*}{ Lecturer } & $\begin{array}{l}\text { Assistant } \\
\text { professor }\end{array}$ & .15 & .09 & .43 \\
\hline & & $\begin{array}{l}\text { Associate } \\
\text { professor }\end{array}$ & $-.64^{*}$ & .14 & .00 \\
\hline & & Postgraduate & -.13 & .06 & .22 \\
\hline & \multirow[t]{2}{*}{ Assistant professor } & $\begin{array}{l}\text { Associate } \\
\text { professor }\end{array}$ & $-.80^{*}$ & .16 & .00 \\
\hline & & Postgraduate & $-.29^{*}$ & .09 & .01 \\
\hline & Associate professor & Postgraduate & $.51^{*}$ & .14 & .00 \\
\hline \multirow{6}{*}{$\begin{array}{l}\text { Responsiveness of } \\
\text { teaching and learning } \\
\text { policy on global } \\
\text { knowledge economy }\end{array}$} & \multirow{3}{*}{ Lecturer } & $\begin{array}{l}\text { Assistant } \\
\text { professor }\end{array}$ & .15 & .12 & .62 \\
\hline & & $\begin{array}{l}\text { Associate } \\
\text { professor }\end{array}$ & .24 & .18 & .63 \\
\hline & & Postgraduate & -.07 & .07 & .84 \\
\hline & \multirow[t]{2}{*}{ Assistant professor } & $\begin{array}{l}\text { Associate } \\
\text { professor }\end{array}$ & .08 & .20 & .98 \\
\hline & & Postgraduate & -.23 & .11 & .24 \\
\hline & Associate professor & Postgraduate & -.31 & .18 & .38 \\
\hline \multirow{6}{*}{$\begin{array}{l}\text { Responsiveness of } \\
\text { research and } \\
\text { innovation policy on } \\
\text { global knowledge } \\
\text { economy }\end{array}$} & \multirow{3}{*}{ Lecturer } & $\begin{array}{l}\text { Assistant } \\
\text { professor }\end{array}$ & -.02 & .12 & .99 \\
\hline & & $\begin{array}{l}\text { Associate } \\
\text { professor }\end{array}$ & .31 & .19 & .44 \\
\hline & & Postgraduate & -.08 & .08 & .80 \\
\hline & \multirow[t]{2}{*}{ Assistant professor } & $\begin{array}{l}\text { Associate } \\
\text { professor }\end{array}$ & .34 & .21 & .45 \\
\hline & & Postgraduate & -.05 & .11 & .97 \\
\hline & Associate professor & Postgraduate & -.40 & .18 & .21 \\
\hline \multirow{6}{*}{$\begin{array}{l}\text { Responsiveness of } \\
\text { university policies on } \\
\text { local and global } \\
\text { engagement }\end{array}$} & \multirow{3}{*}{ Lecturer } & $\begin{array}{l}\text { Assistant } \\
\text { professor }\end{array}$ & .11 & .14 & .90 \\
\hline & & $\begin{array}{l}\text { Associate } \\
\text { professor }\end{array}$ & $1.06^{*}$ & .22 & .00 \\
\hline & & Postgraduate & .11 & .09 & .71 \\
\hline & \multirow[t]{2}{*}{ Assistant professor } & $\begin{array}{l}\text { Associate } \\
\text { professor }\end{array}$ & $.95^{*}$ & .24 & .91 \\
\hline & & Postgraduate & .00 & .13 & .01 \\
\hline & Associate professor & Postgraduate & $-.95^{*}$ & .22 & .00 \\
\hline \multirow{6}{*}{$\begin{array}{l}\text { Responsiveness of } \\
\text { university policy on } \\
\text { graduate } \\
\text { employment demand } \\
\text { in the global context }\end{array}$} & \multirow{3}{*}{ Lecturer } & $\begin{array}{l}\text { Assistant } \\
\text { professor }\end{array}$ & .21 & .16 & .63 \\
\hline & & $\begin{array}{l}\text { Associate } \\
\text { professor }\end{array}$ & .32 & .26 & .05 \\
\hline & & Postgraduate & -.02 & .11 & .99 \\
\hline & \multirow[t]{2}{*}{ Assistant professor } & $\begin{array}{l}\text { Associate } \\
\text { professor }\end{array}$ & .60 & .28 & .20 \\
\hline & & Postgraduate & -.24 & .15 & .49 \\
\hline & Associate professor & Postgraduate & -.35 & .25 & .07 \\
\hline
\end{tabular}

\section{*. The mean difference is significant at the 0.05 level. *. level.; MD: Mean} Difference,SE:Standard Error

From the post hocanalysis computed in Table 2, associate professors showed statistically significant differences with other respondents in terms of their conceptual understanding of the realities of globalisation. For instance, Table 2 depicts that statistically, there was a significant difference between associate professors and other respondents ( $M D=1.06, p=0.00$ ) 
with regard to the responsiveness of Ethiopian universities policy on local and global engagement. These differences might be the result of the respondents' background, experience and rank.

With regard to Ethiopian universities' policy responsiveness to teaching and learning; research and innovation and graduate employment, there is no statistically significant difference observed among respondents. With regard to understanding the realities of globalisation, there is a statistically significant difference between lecturers and associate professors $(\mathrm{MD}=-.64, p=$ .00 ), between assistant professor and associate professors (MD $=-.80, p=0.00$ ) and associate professors with postgraduate students ( $\mathrm{MD}=.51, p=0.00$ ). The respondents' differences regarding the realities of globalisation can be ascribed to their experience either at local or global level. In all cases regarding what globalisation is all about, associate professors responded differently from the other respondents. This shows that higher education professors observed the institutional responsiveness towards global discourse and global knowledge critically in the same way.Furthermore, Table 3 below shows the respondents' understanding of the general impact of globalisation on Ethiopian higher education policy.

Table 3: Analysis of globalisation impact on higher education

\begin{tabular}{|c|c|c|c|c|c|c|c|c|}
\hline & & \multicolumn{4}{|c|}{ Respondents } & \multirow[b]{2}{*}{ Total } & \multirow[b]{2}{*}{$\chi^{2}$} & \multirow[b]{2}{*}{$P$} \\
\hline & & Lecturer & $\begin{array}{l}\text { Assistant } \\
\text { professor }\end{array}$ & $\begin{array}{l}\text { Associate } \\
\text { professor }\end{array}$ & $\begin{array}{c}\text { Postgraduate } \\
\text { students }\end{array}$ & & & \\
\hline Do you think that & Yes & 123 & 45 & 20 & 207 & $395(77.5 \%)$ & & \\
\hline $\begin{array}{l}\text { globalisationaffects } \\
\text { Ethiopian higher } \\
\text { education policy? }\end{array}$ & No & 33 & 16 & 0 & 66 & $115(22.5 \%)$ & 6.88 & 0.07 \\
\hline
\end{tabular}

Table 3 shows that the majority of the respondents $(77.5 \%)$ believe that globalisation affects Ethiopian higher education policy. However, Table 3 depicts that there was no statistically significant difference $(\chi 2=6.88, p>0.05)$ among the respondents occupying different academic ranks. In spite of the differences observed among the respondents regarding the realities of globalisation and institutional policy responsiveness to globalisation in Tablesabove indicates that, regardless of rank, academic staff and students were aware of the impact of globalisation on Ethiopian higher education policies.

As mentioned in the review of Ethiopian higher education, the Bologna process is gaining the upper hand as part of the globalisation discourse influencing policies on higher education. Ethiopian universities are currently implementing the Bologna processes. Table 4 presents respondents' responses to the influence of the Bologna process in Ethiopian universities. 
Table 4: Analysis of realities of Bologna process by respondents

\begin{tabular}{|c|c|c|c|c|c|c|c|c|}
\hline & & \multicolumn{4}{|c|}{ Respondents } & \multirow[b]{2}{*}{ Total } & \multirow[b]{2}{*}{$\chi 2$} & \multirow[b]{2}{*}{$p$} \\
\hline & & Lecturer & $\begin{array}{l}\text { Assistant } \\
\text { professor }\end{array}$ & $\begin{array}{l}\text { Associate } \\
\text { professor }\end{array}$ & Postgraduate & & & \\
\hline $\begin{array}{l}\text { Do you think } \\
\text { that Bologna } \\
\text { process has an }\end{array}$ & Yes & 55 & 35 & 20 & 141 & $251(50.9 \%)$ & & \\
\hline $\begin{array}{l}\text { Ethiopian higher } \\
\text { education } \\
\text { policy? }\end{array}$ & No & 92 & 23 & 1 & 126 & $242(49.1 \%)$ & 29.07 & 0.01 \\
\hline $\begin{array}{l}\text { Do you see } \\
\text { Bologna process }\end{array}$ & Yes & 90 & 27 & 3 & 77 & $197(47.9 \%)$ & & \\
\hline $\begin{array}{l}\text { opportunities for } \\
\text { Ethiopian higher } \\
\text { education? }\end{array}$ & No & 52 & 26 & 15 & 121 & $214(52.1 \%)$ & 27.30 & 0.01 \\
\hline
\end{tabular}

Table 4shows two distinct features observed concerning the impact of the Bologna process on Ethiopian universities. There was a statistically significant difference $\left(\chi^{2}=29.674, p=0.01\right)$ between the respondents regarding the impact of the Bologna process on the current global discourse. This shows that academicstaff and postgraduate students do not share a clear picture of the process in the context of current global demands.

On the other hand, the majority of the respondents $(52.1 \%)$ did not see the Bologna process creating an opportunity for Ethiopian higher education to engage in global discourse. These findings demonstrate that Ethiopian universities are practising the Bologna process without a sound understanding of whether the process would create opportunities for Ethiopian higher education policies to respond to the global demands. This is why there is a statistically significant difference regarding theresponsiveness of the Bologna process $(\chi 2=29.67, p=0.01)$ and the opportunities it may create $\left(\chi^{2}=27.30, p=0.01\right)$ for universities to respond to the global knowledge demands. One can clearly understand why academics criticised the notion that the Bologna process plays a vital role in standardising Ethiopian higher education. However, the Ethiopian government and the Ministry of Education see the Bologna process as the only means of standardising the Ethiopian higher education curriculum.

Table 5: Descriptive summary on realities of globalisation by respondents

\begin{tabular}{|c|c|c|c|c|c|c|}
\hline \multirow[b]{2}{*}{$\begin{array}{l}\text { Ranks of } \\
\text { Respondents }\end{array}$} & \multirow[b]{2}{*}{$\begin{array}{c}\text { Mean } \\
\text { \&Skewness }\end{array}$} & \multicolumn{5}{|c|}{ Policy Area Descriptions } \\
\hline & & $\begin{array}{l}\text { Realities of } \\
\text { globalisation }\end{array}$ & $\begin{array}{l}\text { Teaching } \\
\text { learning }\end{array}$ & $\begin{array}{c}\text { Research } \\
\& \\
\text { innovation }\end{array}$ & $\begin{array}{c}\text { Local and } \\
\text { global } \\
\text { engagement }\end{array}$ & $\begin{array}{c}\text { Graduate } \\
\text { employment } \\
\text { demand }\end{array}$ \\
\hline \multirow[t]{2}{*}{ Lecturer } & $\mathrm{M}$ & 3.82 & 3.19 & 3.10 & 3.30 & 2.53 \\
\hline & Skew & -1.15 & -.40 & -.02 & -.34 & .19 \\
\hline \multirow[t]{2}{*}{ Ass. Prof } & $\mathrm{M}$ & 3.66 & 3.02 & 3.17 & 3.18 & 2.33 \\
\hline & Skew & -.68 & .08 & -.08 & -.33 & .20 \\
\hline \multirow[t]{2}{*}{ Ass. Prof } & $\mathrm{M}$ & 4.51 & 2.94 & 2.82 & 2.21 & 1.70 \\
\hline & Skew & -.77 & .06 & .23 & .86 & 1.59 \\
\hline \multirow[t]{2}{*}{ Post. Grad.St } & $\mathrm{M}$ & 3.95 & 3.22 & 3.20 & 3.17 & 2.55 \\
\hline & Skew & -.46 & -.10 & -.30 & -.37 & .20 \\
\hline \multirow[t]{2}{*}{ Grand Total } & $\mathrm{M}$ & 3.90 & 3.17 & 3.15 & 3.17 & 2.48 \\
\hline & Skew & -.81 & -.16 & -.18 & -.36 & .24 \\
\hline
\end{tabular}

*The more negatively skewed mean,the more optimistic to the given feature; the more positively skewed, the more pessimistic to the given feature 
Table 5shows that the associate professors were more optimistic about globalisation $(\mathrm{M}=4.51$, Skew $=-.77$ ) than the other respondents. Table 5 also shows that associate professors were less optimistic about their institutional policy responsiveness in the area of teaching and learning, research and innovation and policies that relate to local and global engagement. On the other hand, lecturers and postgraduate students were more optimistic regarding their institutional policy responsiveness to teaching and learning, research and innovation and local and global engagement in the context of globalisation. However, all the respondents were pessimistic about university responsiveness policy on graduate employment demands as seen from a global perspective.

From Table 5, one can see how far apart the respondents' views were with regard to the responsiveness of teaching and learning, research and innovation and local and global engagement to current global knowledge demands. The gap between associate professors and lecturers and postgraduate students was well-articulated. From the analyses shown in Tables 1 to Table 5, it can be concluded that respondents had different views about the policy responsiveness of their institution in line with the realities of globalisation. The analyses done werebased on the rank of the respondents, exposure to a conceptual understanding of globalization andtheir institutional responsiveness seems nonexistent.

In the preceding sections, the analyses regarding the realities of globalisationwere made per respondents' academic rank and experience. In all the cases regarding the analyses, institutional policy responsiveness to the realities of globalisation, statistically significant differences were observed between associate professors and other respondents. The following section is devoted to the analyses of institutional policy responsiveness at a particular institutional level.

Table 6: Descriptive summary of realities of globalisation at institutional level

\begin{tabular}{|c|c|c|c|c|c|c|}
\hline \multirow[b]{2}{*}{ Universities } & \multirow[b]{2}{*}{$\begin{array}{c}\text { Mean } \\
\text { \&Skewness }\end{array}$} & \multicolumn{5}{|c|}{ Policy Area Descriptions } \\
\hline & & $\begin{array}{c}\text { Conceptual } \\
\text { Understanding } \\
\text { of Globalisation }\end{array}$ & $\begin{array}{l}\text { Teaching } \\
\text { and } \\
\text { Learning }\end{array}$ & $\begin{array}{l}\text { Research } \\
\text { and } \\
\text { Innovation }\end{array}$ & $\begin{array}{l}\text { Local and } \\
\text { global } \\
\text { engagement }\end{array}$ & $\begin{array}{c}\text { Graduate } \\
\text { employment and } \\
\text { demand } \\
\text { assessment }\end{array}$ \\
\hline \multirow{2}{*}{$\begin{array}{l}\text { Addis } \\
\text { Ababa }\end{array}$} & M & 3.93 & 2.94 & 2.67 & 2.71 & 2.09 \\
\hline & Skew & -0.94 & 0.36 & 0.42 & 0.19 & 0.78 \\
\hline \multirow{2}{*}{ Bahir Dar } & $\mathrm{M}$ & 3.7 & 3.17 & 3.26 & 3.29 & 2.84 \\
\hline & Skew & -0.59 & -0.08 & 0.14 & -0.27 & 0.22 \\
\hline \multirow{2}{*}{ Haramaya } & $\mathrm{M}$ & 3.89 & 3.45 & 3.37 & 3.47 & 2.46 \\
\hline & Skew & -0.46 & -0.45 & -0.22 & -0.47 & 0.31 \\
\hline \multirow{2}{*}{ Hawassa } & $\mathrm{M}$ & 3.98 & 2.88 & 3.02 & 2.86 & 2.21 \\
\hline & Skew & -0.16 & 0.05 & -0.14 & -0.09 & 0.33 \\
\hline \multirow{2}{*}{ Jimma } & $\mathrm{M}$ & 3.81 & 3.48 & 3.31 & 3.45 & 2.89 \\
\hline & Skew & -0.89 & -0.38 & -0.16 & -0.16 & 0.05 \\
\hline \multirow{2}{*}{ Mekelle } & $\mathrm{M}$ & 3.96 & 3.19 & 3.25 & 3.15 & 2.41 \\
\hline & Skew & -0.01 & -0.24 & -0.17 & -0.47 & 0.22 \\
\hline \multirow{2}{*}{$\begin{array}{l}\text { Overall } \\
\text { mean } \\
\text { \&skewness } \\
\end{array}$} & $\mathrm{M}$ & 3.87 & 3.13 & 3.15 & 3.16 & 2.48 \\
\hline & Skew & -0.75 & -0.14 & -0.19 & -0.38 & 0.24 \\
\hline
\end{tabular}

*The more negatively skewed mean,the more optimistic to the given feature; the more positively skewed, the more pessimistic to the given feature

Table 6 shows that all the sampled universities shared a similar and optimistic view $(\mathrm{M}=3.87$, Skew $=-.75$ ) about the realities of globalisation. The sampled universities had similar policy 
practices and they were pessimistic about graduate employment demand $(M=2.48$, skew $=.24$ ). However, differences were observed with regard to institutional policies on teaching andlearning, research and innovation and local and global engagement. For instance, Table 6 shows that the institutional policy responsiveness in teaching and learning in the case of the Haramaya University $(M=3.45$, Skew $=-.45)$, and the Jimma University $(M=3.48$, Skew $=-.48)$ was better for teaching and learning compared to other universities. With regard to research and innovation, local and global engagement, all the universities, except the Addis Ababa University were less optimistic about their institutional policy responsiveness to globalisation.The Addis Ababa University was more pessimistic with regard to its institutional policy responsiveness on research and innovation and on local and global engagements compared to the other universities.

To validate the quantitative data on the conceptual understanding of the realities of globalisation and its impact on higher education policies, the views and perceptions of respondents in sampled universities are presented as follows:

In fact globalisation, from theory and principle point of view, delimits the capacity of nation-states. Thesole responsibility and accountability in their legal policy development, and decision-making capacity is influenced by globalisation policies. Globalisation rather forces nation-states to exercise new policies and rules underpinning globalisation discourses. As a result, the impact of globalisation affects the Ethiopian higher education policies and practices.

The point made by the above comment confirms one of the principles of globalisation that requires public universities to provide services with the intent of making a profit. Consequently, the government will have to face the challenge of fulfilling its legal mandate of operating within the prescribed policy framework. Furthermore, the participant raised the following points:

In the last two decades, there wereseveral foreign universities flourishing in Ethiopia with the diversified and commercialized mode of delivery in the second and third-year degree programmes. As a result, many officers received tuition in their offices. However, this mode of delivery or teaching and learning is not prescribed in Ethiopian higher education policies and existing legal proclamation. In reality this shows how globalisation affects legal framework of one'shigher education institutions.

The opinion above shows that globalisation could affect one's country's higher education policy potentially in the area of the economic development support system, governance and mode of education delivery that has a bearing on curriculum reformation. Different literature presupposes that global policy discourses mitigate the internationalisation principles of higher education as cross-border education with a different mode of delivery. However, Ethiopian higher education has not yet started commercialising education under the umbrella of internationalisation in response to globalisation. From the focus group discussions carried out with regard to the conceptual understanding of globalisation at one of the sampled universities, a participant remarked:

Theoretically we know globalisation and its impacts; practically it is difficult to say we are in global dimension in our daily activities. We as teachers of higher education are expected to deal a lot with globalisation. Among us there are staff members with qualifications in areas of business, and also geography and international relation studies, but we are not teaching our students about the impact of globalisation. The important thing to be noted 
is that teaching about the impact of globalisation does not need subject specialization. Everybody at higher education should know it. Globalisation discourse, under the umbrella of liberalism, can be extended in education through policy harmonization. As a result, our education is subjected to fragmented policy adjustments, with different consultants in the Ethiopian Ministry of Education. Especially in the last 15 years the curriculum of our higher education policy is not stable. Different consultants came with odd and new ideas of one country; then some modification, forinstance, structural modification like years of study for degree programmes directed from the governing body without the consensus of academicians. Directly or indirectly our higher education are experiencing the influence of globalisation.

At almost all the sampled universities, there is a conceptual understanding of the features of globalisation and its impact. The opportunity gained from the global discourse and challenges to cope with globalization were also well understoodamongthe participants in this study. The main problem is its practicality to engage with current global demands. In this regard, Ethiopian higher education's mid-term, long-term or strategic plans do not address how to make Ethiopian higher education global.

The document analysis indicated that all the Ethiopian universities were adopting their fiveyear plan based on the Ethiopian government's Growth and Transformation Plan (GTP) under the education sector. The Ethiopian government's Growth and Transformation Plan focuses on the long-term national development holistically. However, in the case of higher education, the Ministry of Education together with higher education officers and advisors plan how to internationalise Ethiopian universities in view of the current global knowledge convergence.

However, from the official document analyses undertaken and the strategic plan of the sampled universities consulted, an exhaustive elaboration of student enrollment ration and duplication programmes was made. The documents also gave an exhaustive description of the excellence of mission and vision statements with different slogans. On the other hand, internationalization, as a response to globalisation, was linked directly with the excellence of universities documented in specific programmes. When one university excels in teaching and learning and research and innovation, its power to collaborate with international higher education is high and it obtains a global reputation. In this case, because of its geographical position, the Addis Ababa University located in the capital of the country, has international collaboration and is globally recognised. Foreign studentsarrive with their parents for political diplomacy and are admitted to the university and this encourages cultural integration among university students.

At almost all the sampled Ethiopian universities, it was difficult to get an exhaustive strategic plan of internationalisation that responds to globalisation. In a few cases, such as at the Addis Ababa and Jimma Universities, a five-year strategic plan involving international research collaboration is found. However, these plans had shallow indicators. The strategic plan of each university focussed on recruiting domestic students and teachers only. The plan did not address the recruitment of international students and academics. This shows the inconsistency of the strategic role planning of Ethiopian universities in terms of global and higher education demands. Universities lag behind with regard to addressing the internationalisation of their teaching and learning, research and their engagement with their local demands in their strategic planning formulation. Furthermore, a participant said: 
Our strategic plan is politically influenced. It lacks technical skill, and it is more conceptual. We are forced to implement what is designed by some group of political personnel. Experts with global knowledge dimension do not participate in the formulation of the plan. For instance the graduate mixing policy of students in 30:70 proportions is forced by the ruling party without consensus reached by academicians. The strategy behind the graduate mixing policy was said to increase the graduate in science and technology; to fulfill the manpower required in technology area. However, its local and global dimension in quality and standard required is not clearly articulated. This is why the questioning of strategic planning with the view of making inputs is not acceptable during the formulation process. This is why we say our Universities strategic, and policy formulationare politically influenced. Our strategic plan is not designed within framework of higher educationinternationalisation processes.

Ethiopian higher education policy endorsement in international collaboration and international policy integration for mutual benefit in response to the current global discourse is at its infant stage. The respondent's view shows that the impact of globalisation and its responsive policies and strategies have not yet been articulated in higher education strategic planning at both ministerial level, the Ethiopian Ministry of Education, and at institutional levels.

\section{CONCLUSIONS}

For several decades,globalisation has been conceived as an economic phenomenon, which comprises worldwide economic integration under one policy umbrella. However, the globalisation economic policies including the free market policy,have been shaped according to the principle of 'fit for purpose' for different localities in responding to the difference forces of globalisation. According to the current theories of globalisation, higher education institutions entered into relationships with other social institutions. In responding to global discourses a call for internationalisation of higher education has been made to bring the local and global knowledge convergences that respond to globalisation forces.

The findings of the literature confirm that higher education institutions can play a role in the local and global intersection of the knowledge economy. This canbe realised when universities formulate their institutional policies in line with local needs, particularly socio-economic transformation, global economic competence, knowledge production and knowledge convergences.

In Ethiopian cases, the Bologna process was seen as an opportunity; for the global work placing of professionals, global research and innovation, global cross-border education, student mobility and local development policies endeavors.

As a concluding remark to the literature reviewed, in the global knowledge economy, the role of higher education and the nature of universities require change in policies, practices and systems, with respect to local and global contexts towards a distinctly new, global model of higher education.

According to the empirical data, Ethiopian universities are well aware of the realities of globalisation discourses. However, differences were observed among respondents regarding the impact of globalisation on higher education policy. The empirical data reveal that statistically significant differences were found between lecturers and associate professors and between assistant professors and postgraduate students. 
Regarding the features of globalisation and its impact on the higher education policy, the associate professors responded differently from the other respondents. The data revealed that higher education professors observed the institutional responsiveness regarding global discourse and global knowledge convergences critically. Furthermore, the majority of the respondents $(77.5 \%)$, irrespective of their academic rank, believed that the impact of globalisation affected Ethiopian higher education policy. Most respondents perceived globalisation in terms of forces imposed on a nation state to implement the new policies and rules governed underglobalisation discourses.

At institutional level, a similar understanding was observed regarding viewing the realities of globalisation optimistically. At all the sampled universities, opportunities gained from global discourse and challenges to cope with globalisation were also well understood. Furthermore, the findings of the study indicated that in Ethiopian universities, it is difficult to find an exhaustive strategic plan of internationalisation in response to globalisation. In a few cases, namely, the Addis Ababa, Jimma and Hawssauniversities, thefive-year strategic plans spoke about international research collaboration to gain global reputability. The impact of globalisation and its responsive policies were not reflected in the strategic planning of the sampled universities. This study reveals that Ethiopian higher education policy endorsement in international collaboration and international policy integration for mutual benefit in response to the current global discourse isin its infancy.

As a concluding remark on the findings of the study regarding conceptual understanding of the realities of globalization, it can be said that:

- All universities had a similar understanding of globalisation discourses.

- At the respondents' level, statistically significant differences were observed regarding an understanding of the impact of globalisation on higher education between associate professors and other respondents.

- Most respondents agreed on the opportunities for globalisation for higher education curriculum standardisation, staff and student mobility, global competition, global recruitment and working opportunities. However, a few respondents did not agree with regard to the opportunities offered by globalisation.

- The respondents' views revealed that the impact of globalisation and its responsive policies and strategies had not yet been articulated in higher education strategic planning at either ministerial or university levels.

- Inadequate internationalisation practices in response to globalisation discourses were perpetuated at all the Ethiopian universities.

- At none of the sampled universities was there an exhaustive strategic plan for internationalisation in response to globalisation.

The study concluded with the recommendation that Ethiopian higher education policy makers should scan local and global development policies.

- internationalising higher education policies at an institutional level implies standardising the curriculum

- ensuring the quality of the programme, of global-oriented graduates, of professors engaged in teaching-learning and research and innovation to respond to both the local and global knowledge economy. 


\section{References}

Aarts, H.\& Heinz, G. (2010). Globalization, knowledge and learning: Developing the capacities of higher education institutes. In D. Tefera. (Eds), Globalization and African higher education (pp. 9-18). Maastrich: Maastricht University Centre for International Cooperation

Altbach, P. (2007). The "Dilemmas of Ranking", International Higher Education,. Journal of Studies in International Education, 3 (6), 121-133.

Altbach, P.G. and Knight, J. (2007). The Internationalization of higher education:Motivations and Realities. Journal of Studies in International Education, 3(1), 290-293.

Altbach,P.G., Reisberg,L. \& Rumbley,E. (2009). Trends in Global Higher Education:Tracking an Academic Revolution ;A Report Prepared for the UNESCO 2009 World Conference on Higher Education. Paris: UNESCO

Altback,P.G. \& Knight,J. (2006). The Internationalization of Higher Education:Motivations and Realities. Journal of Studies in International Education, 29(2), 3-4.

Ashcroft, K. (2011). Ethiopian Higher Education: Expansion, Dilemmas and Quality. Journal of World Education Services, 23(2), 103-10

Beerkens, H. (2003). Globalisation and Higher Education Research. Journal of Studies International Education, 63(2), 128- 148.

Belay, K. (2006). Linkage of Higher Education with Agricultural Research Extension and Development in Ethiopia. The Ethiopian Journal of Higher Education, 6(1), 21-29.

Burnett,S. (2008). The Impact of Globalisation on Higher Education Institutions in Ontario. Ontario: University of Bath.

Coulby,H. \& Zumbeta,S. (2005). Trends in Globalization. Globalisationand Nationalism in Education,. London: Routhledge Falmer.

Creswell, J. (2003). Research Design: Qualitative, Quantitative, and Mixed Methods Approaches, 2nd Edition. Thousand Oaks, CA: Sage.

Creswell, J. (2009). Mapping the Field of Mixed Methods Research. Journal of Mixed Methods Research, 3(2): 95108.

Crosier, D., \& Parveva, T. (2013). The Bologna Process: Its impact in Europe and beyond. Paris: UNESCO -IIEP

Dale, R. (2005). GlobalisationKnowledge Economy and Comparative Education. Journal of Comparartive Education, $7(3), 117-149$.

Ethiopian Ministry of Education(MOE). (2014). Annual education absract. Addis Ababa: Ministry of Education.

Evans,P. (2011). The Global Challenge: International Human Resorce Management, 2nd ed. New York: McGraw-Hill.

Green, A. (2006). Education,Globalisation and the Nation State. In H.Lauder, P. Brown, J-A. Dillabough \& A.Halsey Eds. Higher Education: handbook of theory and research. New York:Agathon Press.

Guba, E.G., \& Lincoln,Y.S. (1994). Competing paradigm in qualitative research. In K. L. N. Denzin, Handbook of qualitatve research (pp. 105-117). London: Sage.

Knight, J. (2003). Traditionand Transition :The International Perspective in Higher Education. Rotterdom: Sense Publisher.

Knight, J. (2007). Implications of Cross boarder Education and GATS for the Knowledge Enterprise; Report on the UNESCO Forum on Higher Education, Research and Knowledge 2001-2009. Paris: UNESCO.

Knight, J. (2008). Higher education in turmoil: The changing world of internationalization. Rotterdam: Sense Publishers.

Knight, J. (2004). Internationalization remodeled: Definition, approaches, and rationales. International Education Studies,6(2), 5-31.

Marginson,S. \& van der Wende,M. (2009). The New Global Land Scape of Nation and Institution. In OECD, Higher Education to 2030:Volume 2: Globalisation(pp. 17-57). Paris: OECD.

Marmolejo, F. \& Puunka,J. (2006). Supporting the Contribution of Higher Education to Regional Development: Lesson Learned From an OECD Review of 14 Regions. Second Colloquium on Research and Higher Education Policy

" Universities as Centeres of Research and Knowledge Creation (pp. 43-78). Paris: UNESCO. 
Ministry of Education(MOE). (2010). Education Sector Development Programme IV(ESDP-IV) (2010-2014).

Unpublished report, Addis Ababa, FDRE.

Ministry of Education(MoE). (2014). Annual Educational Abstract. Addis Ababa, Ethiopia.

Ministry of Finance and Economic Development(MOFED). (2011). Growth and Transformation Plan Annual Progressive Report,. Addis Ababa, Ethiopia

Mulu, N. (2012). Quality and quality assurance in Ethiopian higher education: critical issues and practical Quality and quality assu Quality and quality assurance in Ethiopian higher education: critical issues and practical Implications. Ph D Dissertation. Enschede: CHEPS.

Onwuegbuzie, A. \& Teddlie, C. (2003). Framework for analyzing data in mixed. In A.Tashakkori, Handbook of mixed (pp. 351-383). Thousand Oaks, CA: Sage.

Ordorika, I. (2006). Higher Education, Research and Innovation:Changing Dynamics. Kassel: INCHER.

Organisation for Economic Co-operation and Development(OECD). (2004). Iternationalization and Trade in Higher Education:Opportunities and Challenges. Paris: OECD Publishing.

Oyewole, O. (2010). Africa and the global knowledge. In D.Tefera, (Eds), Higher education and Globalization:Challenges, threats and opportunities for Africa (pp. 19-30). Maastricht: Alphen a/d Rijn.

Stiglitz, J. (2006). Making Globalisation Work.New York: W.W.Norton \& Company,

Tefera,D. \& Knight,J. (2008). Higher Education in Africa: The International Dimension. Accra: Quali Type Limited.

Teshome, Y. (2003). Transformations in Higher Education: Experiences with Reform and Expansion in Ethiopian Higher Education System. Paper presented on Regional Training Conference on Improving Tertiary Education in Sub Saharan Africa: Accra, September 23- 25, 2003.

UNESCO. (2009). Towards Knowledge Societies. UNESCO World Report. Paris: UNESCO.

Verger, A. (2010). WTO/GATS and The Global Politics of Higher Education. New York: Routledge.

Yang, R. (2002). University Internationalization:Its Meanings, rationales and implications. Journal of intercultural education, 13(1), 81-95. 